\author{
Abstracta Iranica \\ Abstracta Iranica Revue bibliographique pour le domaine irano-aryen \\ Volume 32-33 | 2013 \\ Comptes rendus des publications de 2009-2010
}

\title{
'Alī Owjabī. Sohravardī be-revāyat-e Eškevarī va Ardekānī
}

\section{Mathieu Terrier}

\section{(2) OpenEdition}

1 Journals

\section{Édition électronique}

URL : http://journals.openedition.org/abstractairanica/40537

DOI : 10.4000/abstractairanica.40537

ISSN : 1961-960X

Éditeur :

CNRS (UMR 7528 Mondes iraniens et indiens), Éditions de l'IFRI

\section{Édition imprimée}

Date de publication : 1 décembre 2013

ISSN : 0240-8910

Référence électronique

Mathieu Terrier, « 'Alī Owjabī. Sohravardī be-revāyat-e Eškevarī va Ardekānī », Abstracta Iranica [En

ligne], Volume 32-33 | 2013, document 390, mis en ligne le 01 juillet 2016, consulté le 05 octobre 2020.

URL : http://journals.openedition.org/abstractairanica/40537 ; DOI : https://doi.org/10.4000/ abstractairanica.40537

Ce document a été généré automatiquement le 5 octobre 2020.

Tous droits réservés 


\title{
'Alī Owjabī. Sohravardī be-revāyat-e Eškevarī va Ardekānī
}

\author{
Mathieu Terrier
}

\section{RÉFÉRENCE}

‘Alī Owjabī. Sohravardī be-revāyat-e Eškevarī va Ardekānī. Tehrān, Asāṭīr, 1386/[2008], 117

p.

Cette publication est constituée d'une introduction générale (p. 7-10) et d'une brève monographie sur Sohravardī rédigées par le chercheur et éditeur 'Alī Owjabī (p. 11-32), suivies de la notice, en arabe, consacrée au « maître de l'illumination » par Qoṭb al-Dīn Aškevarī (m. entre 1088/1677 et 1095/1684) dans son encyclopédie des sages intitulée Mạ̣būb al-qulūb (p. 33-66), et de la traduction persane de cette notice par Seyyed Aḥmad Ardekānī au début du XIX e s. (p. 67-94). Le titre du livre est trompeur car il n'y a pas deux « récits » sur Sohravardī mais un seul, celui d'Aškevarī, figure méconnue de la « renaissance philosophique safavide ». La traduction d'Ardekānī omet d'ailleurs la plupart des commentaires personnels de celui-ci pour ne reproduire que la trame prosopographique de sa notice. Le texte de cette dernière a déjà été édité dans Moḥammad b. 'Alī Aškevarī, Maḥbūb al-qulūb, al-maqālat al-țānīya, Téhéran, Mīrāte-e maktūb, 1382 h.š./2003 (p. 345-369). Le seul apport réel de la présente publication est son appareil critique nous renseignant sur les sources d'Aškevarī, qu'il s'agisse des œuvres de Sohravardī citées de première main ou de l'histoire des sages composée par un disciple du šayH al-išrāq, Šams al-Dīn al-Šahrazūrī. Le texte d'Aškevarī, loin d'être un simple assemblage d'informations et de citations, est un essai sur l'unité foncière de la tradition religieuse (prophétique et imamique), de la philosophie d'origine grecque et du soufisme, culminant dans le rapport d'un rêve de Sohravardī visité par Aristote. Le texte donne aussi à entendre ce que l'exemple de vie et le sort tragique de Sohravardī pouvaient avoir comme résonnances à la fin du XI $/ \mathrm{XVII}^{\mathrm{e}} \mathrm{s}$. en Iran safavide. Si l'intérêt éditorial de l'ouvrage est donc mince, il a le mérite d'orienter l'amateur de philosophie, 
déjà plus ou moins familier de Sohravardī, vers l'œuvre originale et méconnue de Qoṭb al-Dīn Aškevarī.

\section{AUTEURS}

\section{MATHIEU TERRIER}

Paris 